Supplement of Atmos. Chem. Phys., 19, 5021-5032, 2019

https://doi.org/10.5194/acp-19-5021-2019-supplement

(C) Author(s) 2019. This work is distributed under

the Creative Commons Attribution 4.0 License.

(c) (1)

Supplement of

\title{
Aqueous reactions of organic triplet excited states with atmospheric alkenes
}

Richie Kaur et al.

Correspondence to: Cort Anastasio (canastasio@ucdavis.edu)

The copyright of individual parts of the supplement might differ from the CC BY 4.0 License. 
Table S1. Reference probes and triplicate measurements of rate constants for alkenes in a solution at $\mathrm{pH}$ 5.5. Errors (in parentheses) for each replicate measurement represent \pm 1 standard error, determined by propagating errors in the slope of the relative rate plot and in the reference compound rate constant. Errors on the average values represent $\pm 1 \sigma$ determined from the average of the replicate values.

\begin{tabular}{|c|c|c|c|c|c|c|c|}
\hline \multirow{2}{*}{ \# } & \multirow{2}{*}{ Alkene Name (ALK) } & \multirow{2}{*}{ Abbreviation } & \multirow{2}{*}{$\begin{array}{c}\text { Reference } \\
\text { Probe }\end{array}$} & \multicolumn{4}{|c|}{$k_{\mathrm{ALK}+3 \mathrm{BP}^{*}}\left(10^{8} \mathrm{M}^{-1} \mathrm{~s}^{-1}\right)$} \\
\hline & & & & $\begin{array}{c}\text { Replicate } \\
1\end{array}$ & $\begin{array}{c}\text { Replicate } \\
2\end{array}$ & $\begin{array}{c}\text { Replicate } \\
3\end{array}$ & $\begin{array}{c}\text { Average } \\
\text { (SD) }\end{array}$ \\
\hline 1 & 5-Hexen-1-ol & $5 \mathrm{HxO}$ & $3 \mathrm{MBO}$ & $3.1(0.4)$ & $1.9(0.3)$ & $2.2(0.3)$ & $2.4(0.6)$ \\
\hline 2 & Allyl alcohol & $\mathrm{AlO}$ & $\mathrm{BDO}$ & $2.8(0.3)$ & $2.5(0.2)$ & $2.8(0.3)$ & $2.7(0.2)$ \\
\hline 3 & 3-Hexene-1,6-diol & HDO & $3 \mathrm{MBO}$ & $2.5(0.4)$ & $3.7(0.5)$ & $3.2(0.4)$ & $3.1(0.7)$ \\
\hline 4 & 2,3-Butadien-1-ol & $\mathrm{BDO}$ & $3 \mathrm{MBO}$ & $3.3(0.5)$ & $3.8(0.5)$ & $3.6(0.5)$ & $3.6(0.3)$ \\
\hline 5 & 3-Buten-1-ol & $3 \mathrm{~B} 1 \mathrm{O}$ & $\mathrm{cHxO}$ & $4.2(0.4)$ & $3.2(0.3)$ & $3.6(0.4)$ & $3.7(0.5)$ \\
\hline 6 & 1-Penten-3-ol & PE3O & $3 \mathrm{~B} 2 \mathrm{O}$ & $3.9(1.1)$ & $4.2(1.2)$ & $4.7(1.3)$ & $4.3(0.4)$ \\
\hline 7 & 3-Buten-2-ol & $3 \mathrm{~B} 2 \mathrm{O}$ & $\mathrm{cHxO}$ & $5.7(0.5)$ & $5.6(0.5)$ & $3.3(0.5)$ & $4.9(1.3)$ \\
\hline 8 & 2-Buten-1-ol & $2 \mathrm{~B} 1 \mathrm{O}$ & $4 \mathrm{M} 3 \mathrm{PO}$ & $5.6(0.2)$ & $4.1(0.3)$ & $5.9(0.5)$ & $5.2(1.0)$ \\
\hline 9 & 5-Hexenyl acetate & $5 \mathrm{HxAc}$ & $3 \mathrm{MBO}$ & $4.7(0.7)$ & $5.0(0.7)$ & $7.9(1.1)$ & $5.9(1.8)$ \\
\hline 10 & trans-3-hexen-1-ol & $\mathrm{tHxO}$ & $3 \mathrm{MBO}$ & $13(2)$ & $14(2)$ & $14(2)$ & $14(1)$ \\
\hline 11 & 1-Chloro-3-methyl-2-butene & CMB & $\mathrm{BDO}^{\mathrm{a}}$ & $17(1)$ & - & - & $17(1)^{\mathrm{b}}$ \\
\hline 12 & 3-Methyl-2-buten-1-ol & $3 \mathrm{MBO}$ & $\mathrm{cHxO}$ & $21(2)$ & $20(2)$ & $16(1)$ & $19(3)$ \\
\hline 13 & 2-Methyl-2-penten-1-ol & $2 \mathrm{M} 2 \mathrm{PO}$ & $3 \mathrm{MBO}$ & $29(4)$ & $28(4)$ & $28(4)$ & $28(1)$ \\
\hline 14 & 4-Methyl-3-penten-1-ol & $4 \mathrm{M} 3 \mathrm{PO}$ & $3 \mathrm{MBO}$ & $42(6)$ & $39(5)$ & $40(5)$ & $40(2)$ \\
\hline 15 & cis-3-hexen-1-ol & $\mathrm{cHxO}$ & $\mathrm{PhOH}$ & $62(11)^{\mathrm{c}}$ & $70(13)$ & $59(11)$ & $64(6)$ \\
\hline 16 & cis-3-hexenyl acetate & $\mathrm{cHxAc}$ & $\mathrm{cHxO}$ & $66(7)$ & $71(6)$ & $59(5)$ & $65(6)$ \\
\hline 17 & Methyl jasmonate & MeJA & $\mathrm{cHxO}$ & $80(7)$ & $69(6)$ & $75(7)$ & $75(5)$ \\
\hline
\end{tabular}

${ }^{\mathrm{a}}$ Measurement of the rate constant for $\mathrm{CMB}$ was done in a solution containing a minimal amount of acetonitrile to dissolve the compound.

${ }^{\mathrm{b}}$ Error represents $\pm 1 \mathrm{SE}$, based on the $\mathrm{SE}$ of the relative rate slope and reference rate constant $k_{\mathrm{BDO}+3 \mathrm{BP} *}$ given in the table.

${ }^{\mathrm{c}}$ Phenol $(\mathrm{PhOH})$ was used as the reference probe using the reference rate constant of $3.9( \pm 0.7) \times 10^{9} \mathrm{M}^{-1} \mathrm{~s}^{-1}$, measured in this study, using 2,4,6,-trimethylphenol (TMP) as a reference compound $\left(k_{\mathrm{TMP}+3 \mathrm{BP}^{*}}=5.1( \pm 0.9) \times 10^{9}\right.$ $\mathrm{M}^{-1} \mathrm{~s}^{-1}$; Canonica et al. (2000)). 
29 Table S2. Highest- and singly-occupied molecular orbitals (HOMOs, SOMOs) of representative alkenes 30 showing removing of an electron from the $\pi$ system. $^{\dagger}$

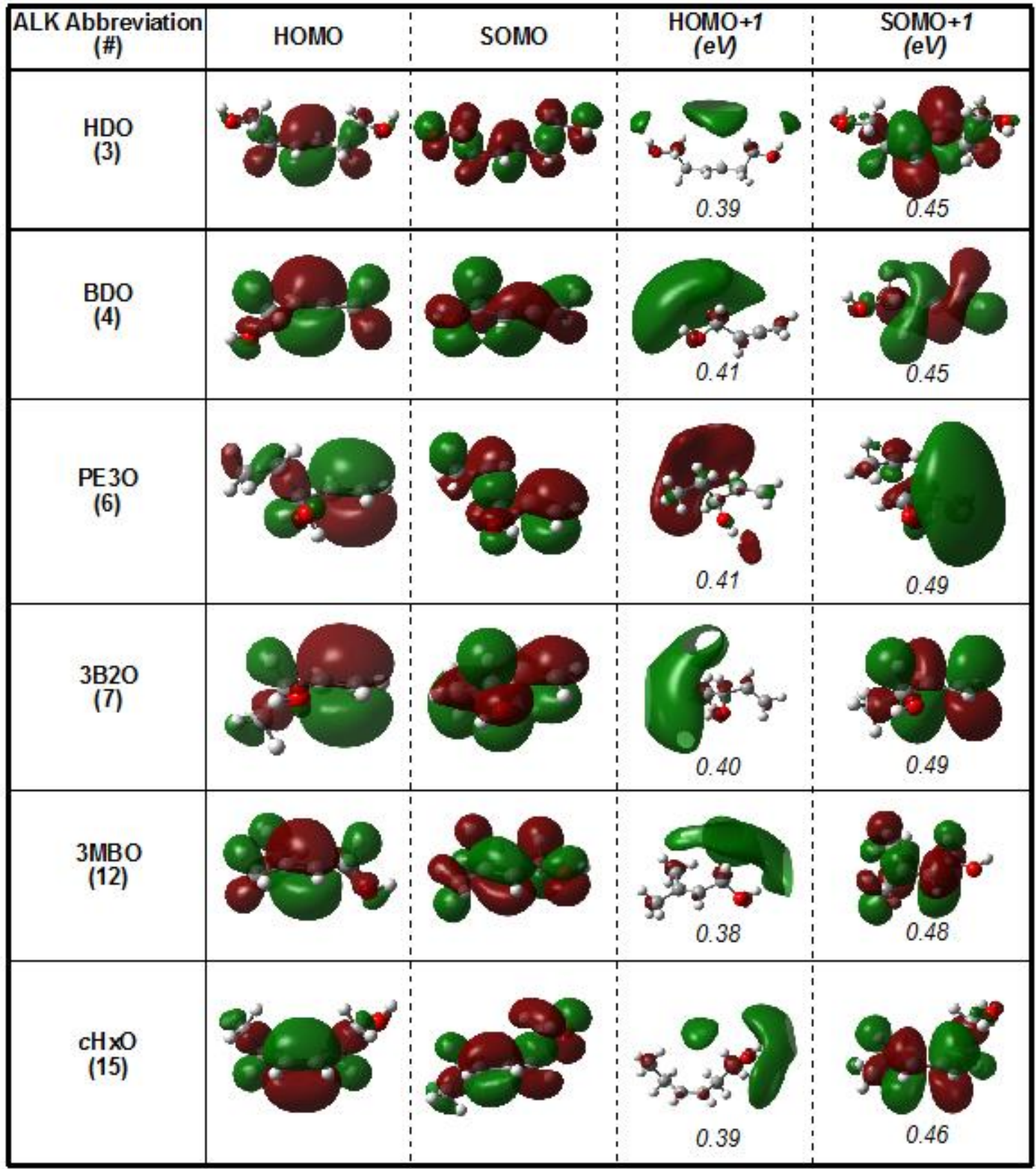

'HOMOs and SOMOs were computed from single point calculations at MP2/CBSB3 (Frisch et al., 33 2016). $\mathrm{HOMO}+1$ and SOMO+1values in $\mathrm{eV}$ are shown relative to HOMO and SOMO, respectively. 
34 Table S3. HOMOs and SOMOs of alkenes showing removing of an electron from the oxygen. ${ }^{\dagger}$

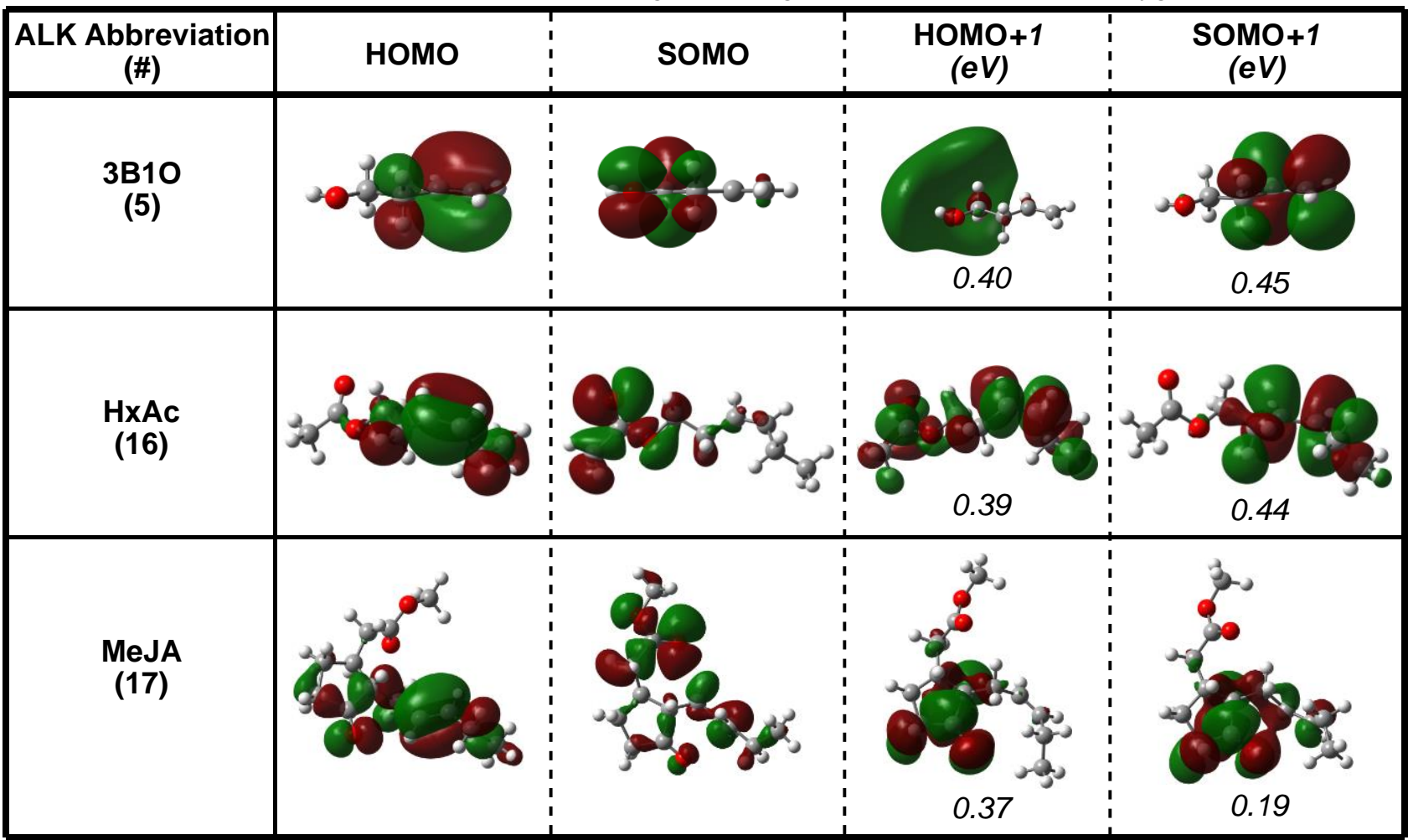

$\dagger_{\text {HOMOs and }}$ SOMOs were computed from single point calculations at MP2/CBSB3 (B3LYP/CBSB7 was used for ALKs 16 and 17). $\mathrm{HOMO}+1$ and $\mathrm{SOMO}+1$ values in $\mathrm{eV}$ are shown relative to $\mathrm{HOMO}$ and $\mathrm{SOMO}$, respectively. 
36 Table S4. Oxidation potentials (in units of $\mathrm{V}$ ) of various isomers of isoprene- and limonene-derived 37 OVOCs, calculated using the CBS-QB3 compound method. The lowest energy isomer for each OVOC 38 is highlighted using a blue box. Compounds not shown here (18, 20 and 22) have no relevant isomers.

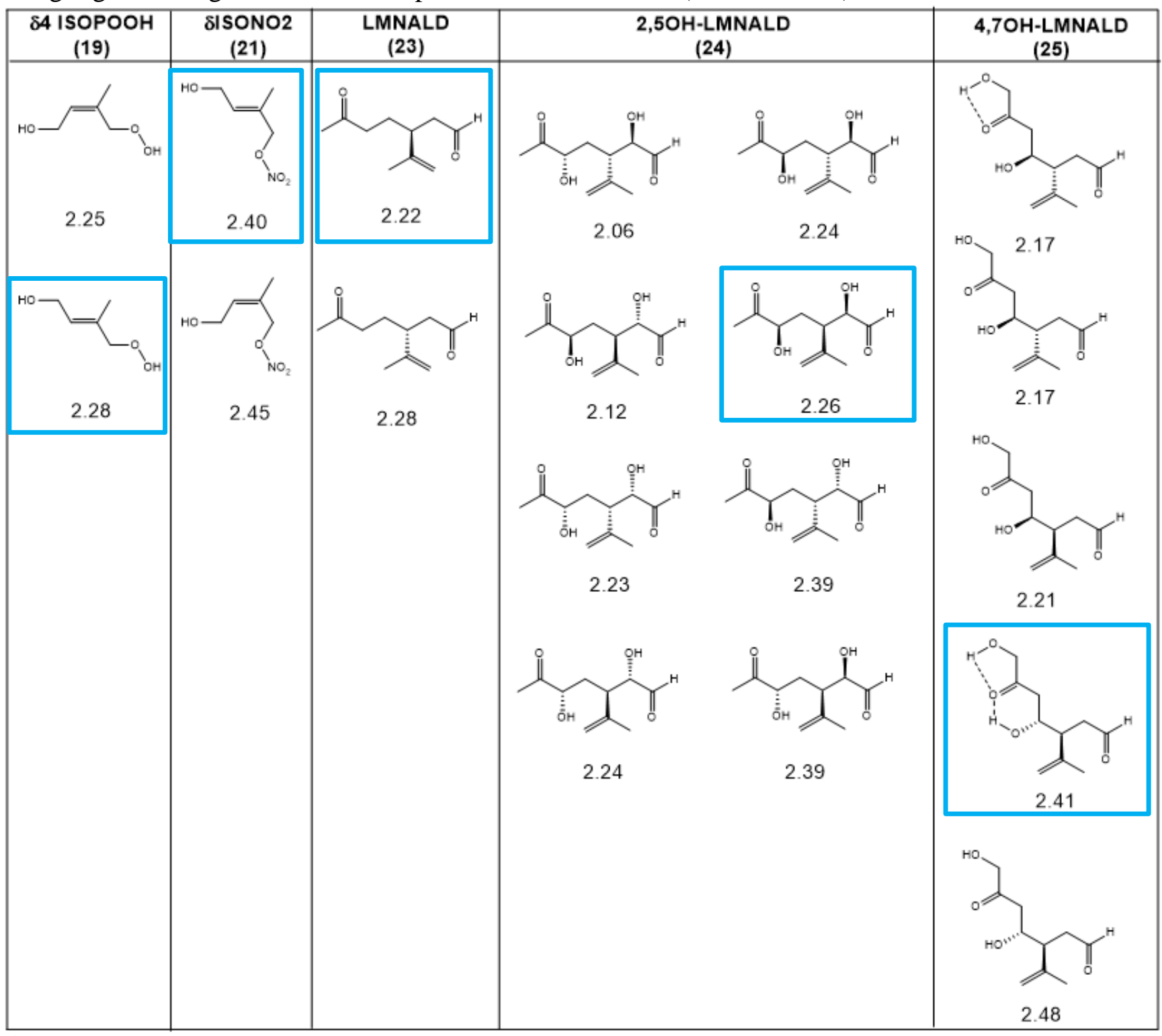


40 Table S5. Measured or estimated rate constants for reactions of OVOCs with oxidants, photolysis, and hydrolysis.

\begin{tabular}{|c|c|c|c|c|c|c|c|}
\hline \multirow[b]{2}{*}{ \# } & \multirow{2}{*}{$\begin{array}{l}\text { OVOC } \\
\text { Name }\end{array}$} & \multicolumn{6}{|c|}{ Gas-phase rate constants $\left(\mathrm{cm}^{3} \mathrm{mlc}^{-1} \mathrm{~s}^{-1}\right)$} \\
\hline & & \multirow{2}{*}{\begin{tabular}{|r|}
$\boldsymbol{k}_{\mathbf{O V O C}+\mathrm{OH}}$ \\
$1.2 \mathrm{E}-10$ \\
\end{tabular}} & \multirow{2}{*}{$\begin{array}{c}\text { Reference } \\
\text { St. Clair et al. (2015) }\end{array}$} & \multirow{2}{*}{$\begin{array}{r}\boldsymbol{k}_{\text {OVOC+O3 }} \\
1.3 \mathrm{E}-17\end{array}$} & \multirow{2}{*}{$\begin{array}{c}\text { Reference } \\
\text { Khamaganov and Hites (2001) }\end{array}$} & \multirow[t]{2}{*}{$\begin{array}{c}\boldsymbol{j}_{\text {Photolysis }} \\
\left(\mathbf{s}^{-1}\right)\end{array}$} & \multirow[t]{2}{*}{ Reference } \\
\hline 18 & $\beta 4-\mathrm{ISOPOOH}$ & & & & & & \\
\hline 19 & $\delta 4-I S O P O O H$ & $1.2 \mathrm{E}-10$ & St. Clair et al. (2015) & $1.3 \mathrm{E}-17$ & Khamaganov and Hites (2001) & & \\
\hline 20 & $\beta$-ISONO2 & $5.4 \mathrm{E}-11$ & Lee et al. (2014) & $5.0 \mathrm{E}-19$ & Lee et al. (2014) & & \\
\hline 21 & $\delta$-ISONO2 & $1.1 \mathrm{E}-10$ & Lee et al. (2014) & $2.8 \mathrm{E}-17$ & Lee et al. (2014) & & \\
\hline 22 & HPALD2 & $5.1 \mathrm{E}-11$ & Wolfe et al. (2012) & $1.2 \mathrm{E}-18$ & Wolfe et al. (2012) & $6.3 \mathrm{E}-05$ & Wolfe et al. (2012) \\
\hline 23 & LMNALD & $1.6 \mathrm{E}-10$ & Gill and Hites (2002) & $2.1 \mathrm{E}-16$ & Khamaganov and Hites (2001) & & \\
\hline 24 & 2,5OH-LMNALD & $1.6 \mathrm{E}-10$ & Gill and Hites (2002) & $2.1 \mathrm{E}-16$ & Khamaganov and Hites (2001) & & \\
\hline 25 & 4,7OH-LMNALD & $1.6 \mathrm{E}-10$ & Gill and Hites (2002) & $2.1 \mathrm{E}-16$ & Khamaganov and Hites (2001) & & \\
\hline 26 & HPALD1 & $5.1 \mathrm{E}-11$ & Wolfe et al. (2012) & $1.2 \mathrm{E}-18$ & Wolfe et al. (2012) & $6.3 \mathrm{E}-05$ & Wolfe et al. (2012) \\
\hline \multirow{2}{*}{\multicolumn{2}{|c|}{ OVOC }} & \multicolumn{6}{|c|}{ Aqueous-phase rate constants $\left(\mathrm{L} \mathrm{mol}^{-1} \mathrm{~s}^{-1}\right)$} \\
\hline & & $k_{\mathrm{OVOC}+\mathrm{OH}}$ & Reference & $k_{\mathrm{OVOC}+\mathrm{O3}}$ & Reference & $\begin{array}{c}k_{\text {Hydrolysis }}^{\prime} \\
\left(\mathbf{s}^{-1}\right)\end{array}$ & Reference \\
\hline 18 & $\beta 4-\mathrm{ISOPOOH}$ & $2.5 \mathrm{E}+09$ & Rivera-Rios et al. (2018) & $4.7 \mathrm{E}+04$ & Schöne and Herrmann $(2014)^{a}$ & & \\
\hline 19 & $\delta 4-I S O P O O H$ & $2.5 \mathrm{E}+09$ & Rivera-Rios et al. (2018) & $4.7 \mathrm{E}+04$ & Schöne and Herrmann (2014) ${ }^{a}$ & & \\
\hline 20 & $\beta$-ISONO2 & $5.0 \mathrm{E}+09$ & Herrmann et al. $(2015)^{b}$ & $4.7 \mathrm{E}+04$ & Schöne and Herrmann (2014) ${ }^{a}$ & $1.6 \mathrm{E}-05$ & Jacobs et al. (2014) \\
\hline 21 & $\delta$-ISONO2 & $5.0 \mathrm{E}+09$ & Herrmann et al. (2015) ${ }^{\mathrm{b}}$ & $4.7 \mathrm{E}+04$ & Schöne and Herrmann $(2014)^{a}$ & $6.8 \mathrm{E}-03$ & Jacobs et al. (2014) \\
\hline 22 & HPALD2 & $9.0 \mathrm{E}+09$ & Schöne et al. (2014) ${ }^{\mathrm{c}}$ & $2.3 \mathrm{E}+04$ & Schöne and Herrmann $(2014)^{c}$ & & \\
\hline 23 & LMNALD & $1.0 \mathrm{E}+10$ & Witkowski et al. (2018) ${ }^{\mathrm{d}}$ & $4.0 \mathrm{E}+04$ & Witkowski et al. (2018) ${ }^{\mathrm{d}}$ & & \\
\hline 24 & 2,5OH-LMNALD & $1.0 \mathrm{E}+10$ & Witkowski et al. (2018) & $4.0 \mathrm{E}+04$ & ${\text { Witkowski et al. }(2018)^{d}}^{d}$ & & \\
\hline 25 & 4,7OH-LMNALD & $1.0 \mathrm{E}+10$ & Witkowski et al. (2018) $^{\mathrm{d}}$ & $4.0 \mathrm{E}+04$ & Witkowski et al. (2018) ${ }^{\mathrm{d}}$ & & \\
\hline 26 & HPALD1 & $9.0 \mathrm{E}+09$ & Schöne et al. $(2014)^{c}$ & $2.3 \mathrm{E}+04$ & Schöne and Herrmann $(2014)^{c}$ & & \\
\hline
\end{tabular}

$41{ }^{a}$ Average of rate constants for methacrolein and methyl vinyl ketone used as a proxy.

$42{ }^{\mathrm{b}}$ Estimate based on the rate constants for similar unsaturated compounds with ${ }^{\circ} \mathrm{OH}$ in the indicated reference.

$43{ }^{\mathrm{c}}$ Rate constant for methacrolein used as a proxy.

$44{ }^{\mathrm{d}}$ Rate constants for neutral dicarbonyl derivatives of limonic and limononic acids, used a proxies. 
Table S6. Loss rate constants for OVOCs due to different pathways.

\begin{tabular}{|c|c|c|c|c|c|c|c|c|c|c|c|}
\hline \multirow[b]{2}{*}{ \# } & \multirow[b]{2}{*}{ OVOC Name } & \multirow[b]{2}{*}{$\begin{array}{c}K_{\mathrm{H}}^{\mathrm{a}} \\
\left(\mathrm{M} \mathrm{atm}^{-1}\right)\end{array}$} & \multirow[b]{2}{*}{$\chi_{\mathrm{aq}}{ }^{\mathrm{b}}$} & \multicolumn{3}{|c|}{$\begin{array}{l}\text { Pseudo-first-order rate constant for } \\
\text { loss due to oxidants in the gas- } \\
\text { phase }\left(\mathrm{s}^{-1}\right)\end{array}$} & \multicolumn{5}{|c|}{$\begin{array}{l}\text { Pseudo-first-order rate constant for loss due to oxidants } \\
\text { in the aqueous-phase }\left(\mathrm{s}^{-1}\right)\end{array}$} \\
\hline & & & & $k_{\mathrm{OH}, \mathrm{g}}^{\prime}{ }^{\mathrm{c}}$ & $k_{\mathrm{O} 3, \mathrm{~g}}^{\prime}{ }^{\mathrm{d}}$ & $j_{\mathrm{hv}}{ }^{\mathrm{e}}$ & $k_{\mathrm{OH}, \mathrm{aq}}^{\prime}{ }^{\mathrm{f}}$ & $k_{\mathrm{O} 3, \mathrm{aq}}^{\prime}{ }^{\mathrm{g}}$ & $\begin{array}{c}k_{3 \mathrm{BP} * \mathrm{aq}}^{\prime}{ }^{\prime} \\
\text { (High } \\
\text { Triplet } \\
\text { Reactivity) }\end{array}$ & $\begin{array}{c}k_{3 \mathrm{C}^{*}, \mathrm{aq}}{ }^{\mathrm{i}} \\
\text { (Typical } \\
\text { Triplet } \\
\text { Reactivity) }\end{array}$ & $k_{\mathrm{Hyd}}^{\prime}{ }^{\mathrm{j}}$ \\
\hline 18 & $\beta 4$-ISOPOOH & $1.5 \mathrm{E}+06$ & 0.97 & $1.2 \mathrm{E}-04$ & 9.6E-06 & & 5.0E-06 & 1.6E-05 & 4.0E-06 & 1.4E-07 & \\
\hline 19 & $\delta 4-I S O P O O H$ & $1.2 \mathrm{E}+06$ & 0.97 & $1.2 \mathrm{E}-04$ & $9.6 \mathrm{E}-06$ & & $5.0 \mathrm{E}-06$ & $1.6 \mathrm{E}-05$ & $6.8 \mathrm{E}-05$ & $2.4 \mathrm{E}-06$ & \\
\hline 20 & $\beta$-ISONO2 & $5.1 \mathrm{E}+04$ & 0.55 & $5.4 \mathrm{E}-05$ & $3.7 \mathrm{E}-07$ & & $1.0 \mathrm{E}-05$ & $1.6 \mathrm{E}-05$ & $2.1 \mathrm{E}-05$ & 7.3E-07 & $1.6 \mathrm{E}-05$ \\
\hline 21 & $\delta$-ISONO2 & $4.3 \mathrm{E}+04$ & 0.51 & $1.1 \mathrm{E}-04$ & $2.1 \mathrm{E}-05$ & & $1.0 \mathrm{E}-05$ & $1.6 \mathrm{E}-05$ & $4.6 \mathrm{E}-05$ & $1.6 \mathrm{E}-06$ & $6.8 \mathrm{E}-03$ \\
\hline 22 & HPALD2 & $1.2 \mathrm{E}+05$ & 0.75 & 5.1E-05 & $8.9 \mathrm{E}-07$ & $6.3 \mathrm{E}-05$ & $1.8 \mathrm{E}-05$ & 7.6E-06 & $2.0 \mathrm{E}-05$ & 7.0E-07 & \\
\hline 23 & LMNALD & $4.5 \mathrm{E}+03$ & 0.10 & $1.6 \mathrm{E}-04$ & $1.6 \mathrm{E}-04$ & & $2.0 \mathrm{E}-05$ & $1.3 \mathrm{E}-05$ & 8.3E-05 & 2.9E-06 & \\
\hline 24 & 2,5OH-LMNALD & $8.0 \mathrm{E}+05$ & 0.95 & $1.6 \mathrm{E}-04$ & 1.6E-04 & & $2.0 \mathrm{E}-05$ & $1.3 \mathrm{E}-05$ & 7.3E-05 & $2.6 \mathrm{E}-06$ & \\
\hline 25 & 4,7OH-LMNALD & $8.0 \mathrm{E}+05$ & 0.95 & $1.6 \mathrm{E}-04$ & 1.6E-04 & & $2.0 \mathrm{E}-05$ & $1.3 \mathrm{E}-05$ & $4.4 \mathrm{E}-05$ & $1.6 \mathrm{E}-06$ & \\
\hline 26 & HPALD1 & $1.2 \mathrm{E}+05$ & 0.75 & $5.1 \mathrm{E}-05$ & 8.9E-07 & $6.3 \mathrm{E}-05$ & $1.8 \mathrm{E}-05$ & $7.6 \mathrm{E}-06$ & $-k$ & $-k$ & \\
\hline
\end{tabular}

$46{ }^{\mathrm{a}}$ Henry's law constants calculated using EPISuite version 4.1 (US EPA. Estimation Programs Interface Suite ${ }^{\mathrm{TM}}$ for Microsoft® Windows v 4.1,

47 2016).

$48{ }^{\mathrm{b}}$ Fraction of OVOC in the aqueous phase, calculated as $\chi_{\mathrm{aq}}=1 /\left(1+1 /\left(K_{\mathrm{H}} \times L \times R \times T\right)\right)$, where $K_{\mathrm{H}}$ is the Henry's law constant of the OVOC, $L$ is the

49 assumed liquid water content $\left(1 \times 10^{-6} \mathrm{~L}-\mathrm{aq} / \mathrm{L}-\mathrm{g}\right), R$ is the universal gas constant $\left(0.082 \mathrm{~L} \mathrm{~atm} \mathrm{~K}^{-1} \mathrm{~mol}^{-1}\right)$, and $T=298 \mathrm{~K}$.

$50 \mathrm{c}, \mathrm{d}, \mathrm{f}, \mathrm{g}, \mathrm{h}, \mathrm{i}$ Pseudo-first-order rate constant for loss of OVOC due to oxidation by the given oxidant in the gas or aqueous phase, calculated by

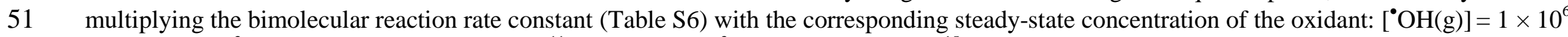
molecules $\mathrm{cm}^{-3},\left[\mathrm{O}_{3}(\mathrm{~g})\right]=30 \mathrm{ppbv}=7.4 \times 10^{11}$ molecules $\mathrm{cm}^{-3},\left[{ }^{\bullet} \mathrm{OH}(\mathrm{aq})\right]=2 \times 10^{-15} \mathrm{M}$ (estimate in typical fog drops, includes gas-to-aqueous partitioning, Kaur and Anastasio (2017)).

$54\left[\mathrm{O}_{3}(\mathrm{aq})\right]=3.3 \times 10^{-10} \mathrm{M}\left(\right.$ based on $30 \mathrm{ppbv} \mathrm{O}_{3}(\mathrm{~g})$ and $K_{\mathrm{H}}=1.1 \times 10^{-2} \mathrm{M} \mathrm{atm}^{-1}$; Seinfeld and Pandis $(2012)$, and $\left.{ }^{3} \mathrm{C}^{*}(\mathrm{aq})\right]=5 \times 10^{-14} \mathrm{M}($ average 55 concentration measured in Davis fog, Kaur and Anastasio (2017)).

$56{ }^{\mathrm{h}}$ Pseudo-first-order rate constant for loss of OVOC due to oxidation by highly reactive triplets such as ${ }^{3} \mathrm{BP} *$. This was calculated using the

57 predicted second-order rate constants $k_{\mathrm{OVOC}+3 \mathrm{BP} *}\left(\right.$ Table 1 , main text) and $\left.{ }^{3} \mathrm{C}^{*}(\mathrm{aq})\right]$ given in the footnote above.

58 i Pseudo-first-order rate constant for loss of OVOC due to oxidation by triplets of typical reactivity as measured in fog and particles in Davis, CA (Kaur and Anastasio, 2017; Kaur and Anastasio, 2018). To estimate these rate constants we multiplied the predicted second-order rate constants with ${ }^{3} \mathrm{BP}^{*}\left(k_{\mathrm{OVOC}+3 \mathrm{BP}}\right)$ by a factor of 0.04 , which is the ratio of the average of the rate constants of reaction of MeJA with ${ }^{3} 3 \mathrm{MAP} *$ and ${ }^{3} \mathrm{DMB} *$

$61 \quad\left(2.7 \times 10^{8} \mathrm{M}^{-1} \mathrm{~s}^{-1}\right.$, Table S8) divided by the rate constant for MeJA with ${ }^{3} \mathrm{BP} *\left(7.5 \times 10^{9} \mathrm{M}^{-1} \mathrm{~s}^{-1}\right.$, Tables S1 and S8).

$62{ }^{e, j}$ First-order rate constants for gas-phase photolysis and aqueous hydrolysis of the OVOC, respectively (also given in Table S5).

$63{ }^{\mathrm{k}}$ The value of $k_{\mathrm{ALK}+3 \mathrm{BP} *}$ for HPALD1 could not be determined due to challenges with calculating its oxidation potential. Because the CB3-QB3

64 method scales at $N^{7}$ (where $N$ is the number of atoms), the larger compound required more computational power than available. 
65 Table S7. OVOC lifetimes and fractions lost due to various pathways.

\begin{tabular}{|c|c|c|c|c|c|c|c|c|c|c|}
\hline \multicolumn{2}{|c|}{ High Triplet Reactivity Scenario } & \multicolumn{2}{|c|}{ Total } & \multicolumn{7}{|c|}{ Fraction of OVOC lost due to each pathway ${ }^{c}$} \\
\hline$\#$ & OVOC Name & $\begin{array}{c}k_{\text {OVOC }}^{\prime a} \\
\left(s^{-1}\right)\end{array}$ & $\begin{array}{l}\tau^{b} \\
(\mathrm{~h})\end{array}$ & ${ }^{\circ} \mathrm{OH}(\mathrm{g})$ & $\mathrm{O}_{3}(\mathrm{~g})$ & $\mathrm{h} v(\mathrm{~g})$ & ${ }^{\circ} \mathrm{OH}(\mathrm{aq})$ & $\mathrm{O}_{3}(\mathrm{aq})$ & ${ }^{3} \mathrm{BP} *(\mathrm{aq})$ & Hyd(aq) \\
\hline 18 & $\beta 4-I S O P O O H$ & $2.7 \mathrm{E}-05$ & 10 & $13 \%$ & $1.0 \%$ & $0 \%$ & $18 \%$ & $54 \%$ & $14 \%$ & $0 \%$ \\
\hline 19 & $\delta 4-I S O P O O H$ & $9.0 \mathrm{E}-05$ & 3.1 & $3.9 \%$ & $0.32 \%$ & $0 \%$ & $5.4 \%$ & $17 \%$ & $74 \%$ & $0 \%$ \\
\hline 20 & $\beta$-ISONO2 & $5.9 \mathrm{E}-05$ & 4.7 & $41 \%$ & $0.28 \%$ & $0 \%$ & $9.4 \%$ & $15 \%$ & $19 \%$ & $15 \%$ \\
\hline 21 & $\delta$-ISONO2 & $3.6 \mathrm{E}-03$ & 0.078 & $1.5 \%$ & $0.29 \%$ & $0 \%$ & $0.14 \%$ & $0.22 \%$ & $0.66 \%$ & $97 \%$ \\
\hline 22 & HPALD2 & $6.3 \mathrm{E}-05$ & 4.4 & $20 \%$ & $0.35 \%$ & $25 \%$ & $21 \%$ & $9.1 \%$ & $24 \%$ & $0 \%$ \\
\hline 23 & LMNALD & $3.0 \mathrm{E}-04$ & 0.93 & $49 \%$ & $47 \%$ & $0 \%$ & $0.67 \%$ & $0.44 \%$ & $2.8 \%$ & $0 \%$ \\
\hline 24 & 2,5OH-LMNALD & $1.2 \mathrm{E}-04$ & 2.4 & $6.9 \%$ & $6.7 \%$ & $0 \%$ & $16 \%$ & $11 \%$ & $59 \%$ & $0 \%$ \\
\hline 25 & 4,7OH-LMNALD & $8.9 \mathrm{E}-05$ & 3.1 & $9.0 \%$ & $8.8 \%$ & $0 \%$ & $21 \%$ & $14 \%$ & $47 \%$ & $0 \%$ \\
\hline 26 & HPALD1 & $4.8 \mathrm{E}-05$ & 5.8 & $27 \%$ & $0.46 \%$ & $33 \%$ & $28 \%$ & $12 \%$ & $-{ }^{d}$ & $0 \%$ \\
\hline \multicolumn{2}{|c|}{ Typical Triplet Reactivity Scenario } & \multicolumn{2}{|c|}{ Total } & \multicolumn{7}{|c|}{ Fraction of OVOC lost due to each pathway $^{c}$} \\
\hline \# & OVOC Name & $\begin{array}{c}k_{\mathrm{OVOC}}^{\prime} \\
\left(\mathrm{s}^{-1}\right)\end{array}$ & $\begin{array}{c}\tau \\
(\mathrm{h})\end{array}$ & ${ }^{\circ} \mathrm{OH}(\mathrm{g})$ & $\mathrm{O}_{3}(\mathrm{~g})$ & $\mathrm{h} v(\mathrm{~g})$ & ${ }^{\circ} \mathrm{OH}(\mathrm{aq})$ & $\mathrm{O}_{3}(\mathrm{aq})$ & ${ }^{3} \mathrm{C} *(\mathrm{aq})$ & Hyd(aq) \\
\hline 18 & $\beta 4-I S O P O O H$ & $2.4 \mathrm{E}-05$ & 12 & $15 \%$ & $1.2 \%$ & $0 \%$ & $20 \%$ & $63 \%$ & $0.58 \%$ & $0 \%$ \\
\hline 19 & $\delta 4-I S O P O O H$ & $2.6 \mathrm{E}-05$ & 11 & $14 \%$ & $1.1 \%$ & $0 \%$ & $19 \%$ & $58 \%$ & $9.0 \%$ & $0 \%$ \\
\hline 20 & $\beta$-ISONO2 & $4.8 \mathrm{E}-05$ & 5.8 & $51 \%$ & $0.43 \%$ & $0 \%$ & $12 \%$ & $18 \%$ & $0.84 \%$ & $18 \%$ \\
\hline 21 & $\delta$-ISONO2 & $3.5 \mathrm{E}-03$ & 0.079 & $1.5 \%$ & $0.29 \%$ & $0 \%$ & $0.14 \%$ & $0.22 \%$ & $0.02 \%$ & $98 \%$ \\
\hline 22 & HPALD2 & $4.8 \mathrm{E}-05$ & 5.7 & $26 \%$ & $0.46 \%$ & $33 \%$ & $28 \%$ & $12 \%$ & $1.1 \%$ & $0 \%$ \\
\hline 23 & LMNALD & $2.9 \mathrm{E}-04$ & 1.0 & $50 \%$ & $49 \%$ & $0 \%$ & $0.69 \%$ & $0.45 \%$ & $0.10 \%$ & $0 \%$ \\
\hline 24 & 2,5OH-LMNALD & $5.0 \mathrm{E}-05$ & 5.6 & $16 \%$ & $16 \%$ & $0 \%$ & $38 \%$ & $25 \%$ & $4.9 \%$ & $0 \%$ \\
\hline 25 & 4,7OH-LMNALD & $4.9 \mathrm{E}-05$ & 5.7 & $16 \%$ & $16 \%$ & $0 \%$ & $39 \%$ & $26 \%$ & $3.0 \%$ & $0 \%$ \\
\hline 26 & HPALD1 & $4.8 \mathrm{E}-05$ & 5.8 & $27 \%$ & $0.46 \%$ & $33 \%$ & $28 \%$ & $12 \%$ & $-^{d}$ & $0 \%$ \\
\hline
\end{tabular}

$66{ }^{a}$ Total pseudo-first order rate constant for loss of OVOC, calculated as $k^{\prime}{ }_{\mathrm{OVOC}}=\Sigma\left(\chi_{\mathrm{aq}} \times k_{\mathrm{Ox}, \mathrm{aq}}^{\prime}+\left(1-\chi_{\mathrm{aq}}\right) \times k_{\mathrm{Ox}, \mathrm{gas}}^{\prime}\right)$. All pseudo-first-order rate

67 constants $\left(k_{\text {Ox,aq }}^{\prime}, k_{\text {Ox,gas }}^{\prime}, j_{\mathrm{hv}}, k_{\text {Hyd }}^{\prime}\right)$ are given in Table S6.

$68{ }^{\mathrm{b}}$ Total lifetime of OVOC, calculated as $1 / k^{\prime}$ OVOC.

$69{ }^{\mathrm{c}}$ Fraction of OVOC lost due to each pathway, calculated as $\left(\chi_{\mathrm{aq}} \times k_{\mathrm{Ox,aq}}^{\prime}\right) / k^{\prime}{ }_{\mathrm{OVOC}}$ for aqueous pathways and $\left(\left(1-\chi_{\mathrm{aq}}\right) \times k_{\text {Ox,gas }}^{\prime}\right) / k^{\prime}$ OvoC for gas-phase 70 processes.

$71{ }^{\mathrm{d}}$ We were unable to compute the oxidation potential for HAPLD1 (see footnote $k$ in Table S6), and thus could not estimate its rate constant with 72 triplets. 
73 Table S8. Second-order rate constants for reaction of some alkenes with model triplet excited states.

\begin{tabular}{|c|c|c|c|c|}
\hline \multirow{2}{*}{ ALK } & \multicolumn{3}{|c|}{$\begin{array}{c}k_{\mathrm{ALK}+3 \mathrm{C}^{*}} \\
10^{8} \mathrm{M}^{-1} \mathrm{~s}^{-1} \\
\end{array}$} & \multirow{2}{*}{$\begin{array}{c}\text { Average }\left(k_{\mathrm{MeJA}+33 \mathrm{MAP} *}, k_{\mathrm{MeJA}+3 \mathrm{DMB} *}\right) / \\
k_{\mathrm{MeJA}+3 \mathrm{BP} *}{ }^{*}\end{array}$} \\
\hline & ${ }^{3} 3 \mathrm{MAP} *$ & ${ }^{3} \mathrm{DMB}^{*}$ & ${ }^{3} \mathrm{BP}^{*}$ & \\
\hline cHxO (15) & $1.1( \pm 0.2)^{\mathrm{a}}$ & $0.24( \pm 0.10)^{\mathrm{a}}$ & $64( \pm 6)^{b}$ & 0.010 \\
\hline cHxAc (16) & $7.9( \pm 2.0)^{\mathrm{a}}$ & $15( \pm 4)^{\mathrm{a}}$ & $65( \pm 6)^{b}$ & 0.18 \\
\hline MeJA (17) & $1.2( \pm 0.3)^{\mathrm{a}}$ & $4.1( \pm 1.6)^{\mathrm{a}}$ & $75( \pm 5)^{b}$ & $0.035^{d}$ \\
\hline
\end{tabular}

${ }^{\mathrm{a}}$ Rate constants from Richards-Henderson et al. (2014). Listed uncertainties are \pm 1 standard errors.

${ }^{\mathrm{b}}$ Rate constants measured in this work (also shown in Table S1). Listed uncertainties here are \pm 1 standard deviation, $\mathrm{n}=3$.

${ }^{\mathrm{c}}$ The ratio of the average bimolecular rate constants for reaction of MeJA with model triplets ${ }^{3} 3 \mathrm{MAP} *$ and ${ }^{3} \mathrm{DMB}^{*}$ to the rate constant for MeJA with ${ }^{3} \mathrm{BP} *$.

${ }^{\mathrm{d}}$ This is the rate constant ratio for MeJA as well as the median value of the rate constant ratio (see footnote $a$ ) 80 for the three alkenes. 


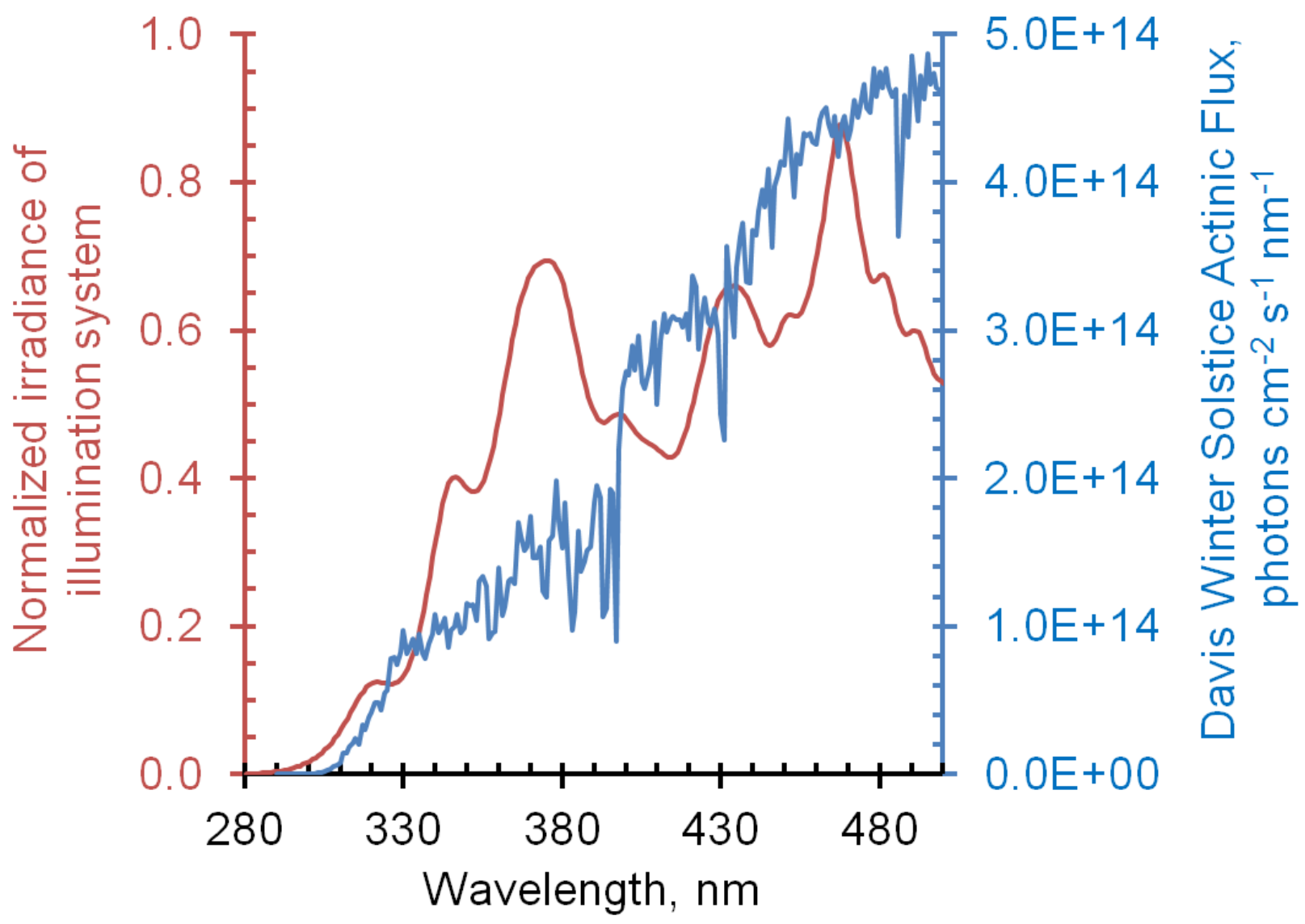

Figure S1. Comparison of the normalized irradiance from our illumination system (red line) and Davis, midday, winter solstice sunlight from the TUV model (blue line; Madronich et al. (2002)). Our illumination system irradiance was measured using a TIDAS spectrophotometer (absolute units: counts $\mathrm{cm}^{-2} \mathrm{~nm}^{-1} \mathrm{~s}^{-1}$ ) and normalized so that the area under its curve is equal to the area under the TUV actinic flux curve. Input parameters for the TUV model were: solar zenith angle: $62^{\circ}$, measurement altitude: $0 \mathrm{~km}$, surface albedo: 0.1 , aerosol optical depth: 0.235 , cloud optical depth: 0.00 . 

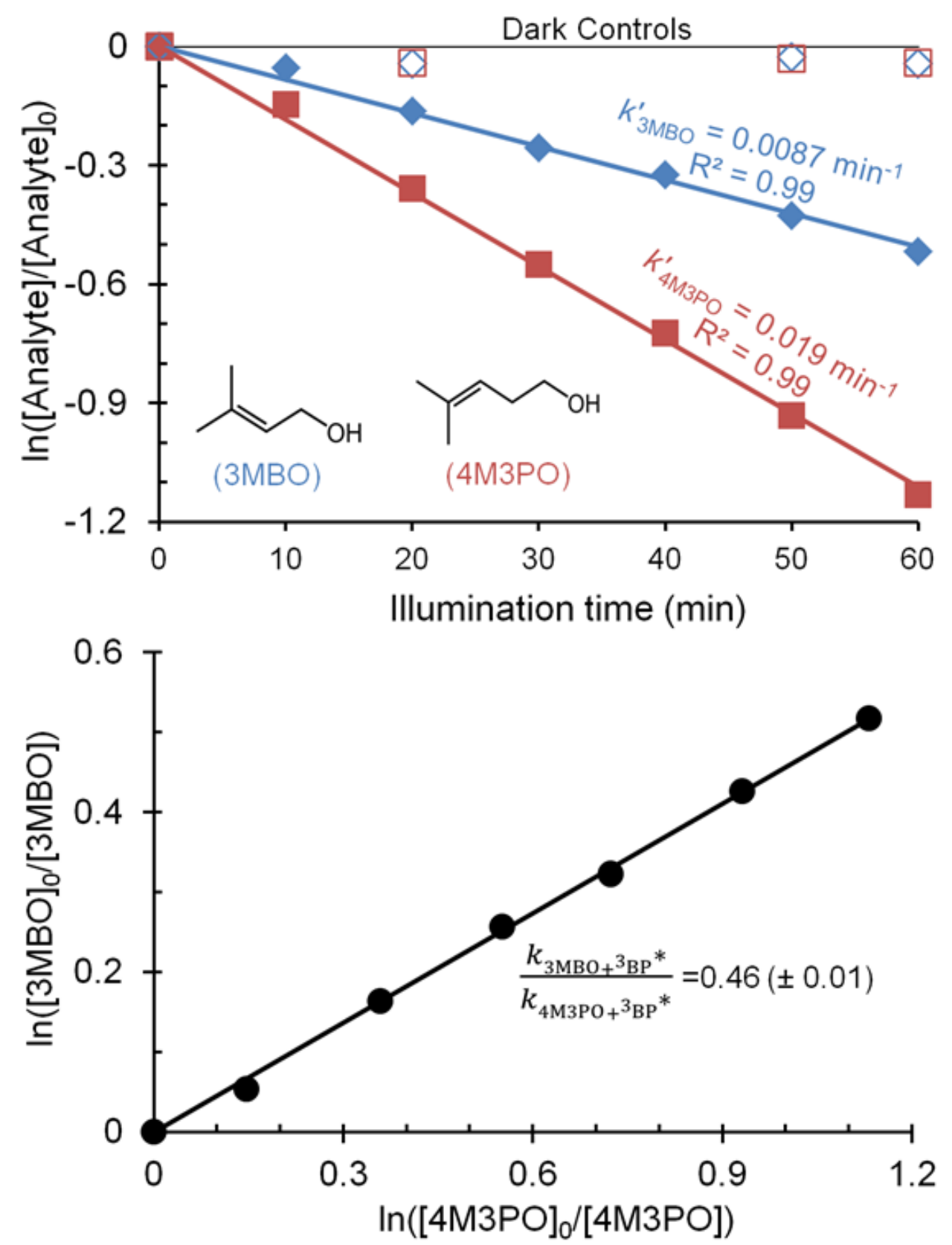

Figure S2. Illustration of the relative rate technique used for measuring rate constants

94 (Finlayson-Pitts and Pitts Jr, 1999; Richards-Henderson et al., 2014). Top panel: Aqueous loss of 95 the alkene (4M3PO) and reference compound (3MBO) in the presence of the BP triplet under 96 solar simulated light $(298 \mathrm{~K}, \mathrm{pH} 5.5( \pm 0.2))$. Bottom panel: Plot of change in concentration of 97 reference compound against alkene. The slope represents the ratio ( $\pm 1 \mathrm{SE}$ ) of the bimolecular 98 rate constants with the BP triplet. 


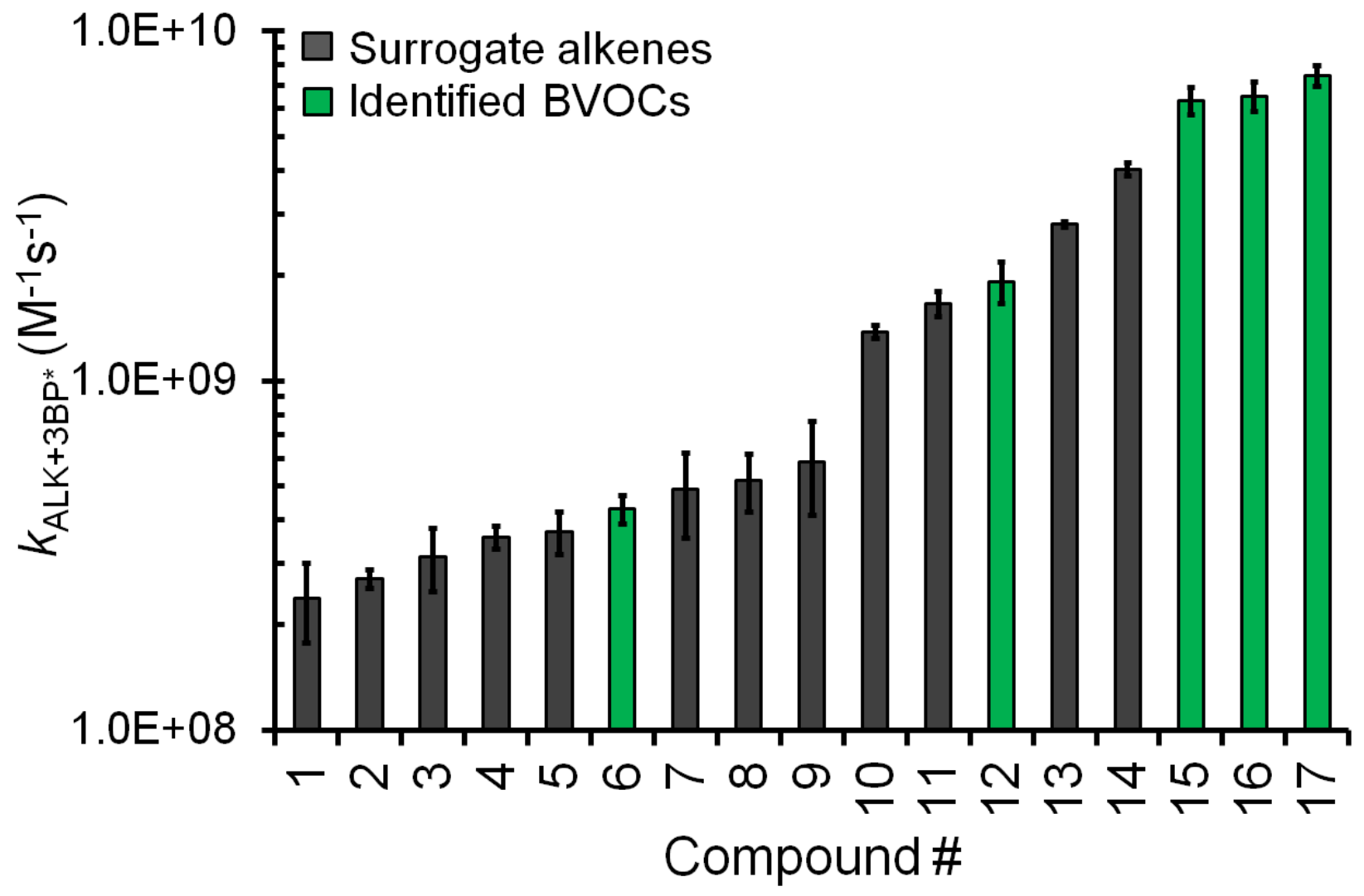

102 Figure S3. Measured bimolecular rate constants of 17 alkenes with triplet benzophenone. Green 103 bars represent biogenic volatile organic compounds known to be emitted from plants; grey bars 104 represent other $\mathrm{C}_{3}-\mathrm{C}_{6}$ alkenes. Error bars represent \pm 1 standard deviation $(\mathrm{n}=3)$ except for 105 compound 11, where $\mathrm{n}=1$ and the error is $\pm 1 \mathrm{SE}$ (see Table $\mathrm{S} 1$ for details). Experimental 106 conditions: $298 \mathrm{~K}, \mathrm{pH} 5.5 \pm 0.2,1.0 \mathrm{mM}$ phosphate buffer). 


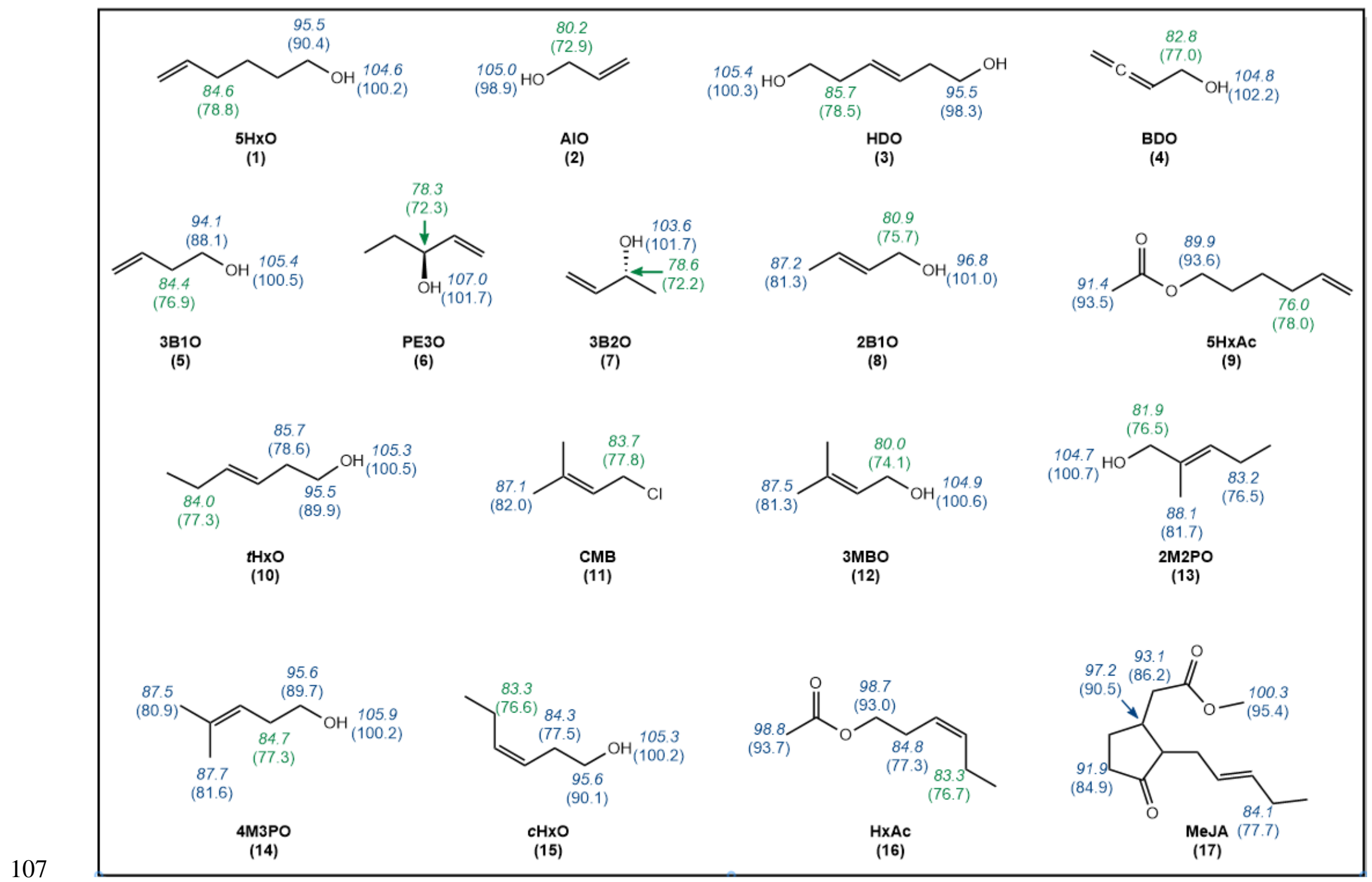

108 Figure S4. Bond dissociation enthalpies (in italics) and bond dissociation free energies (in parentheses) in $\mathrm{kcal} \mathrm{mol}^{-1}$ for various 109 hydrogens in each alkene. For each compound the hydrogen most likely to be abstracted, i.e., with the lowest bond dissociation 110 energy, is shown in green. 

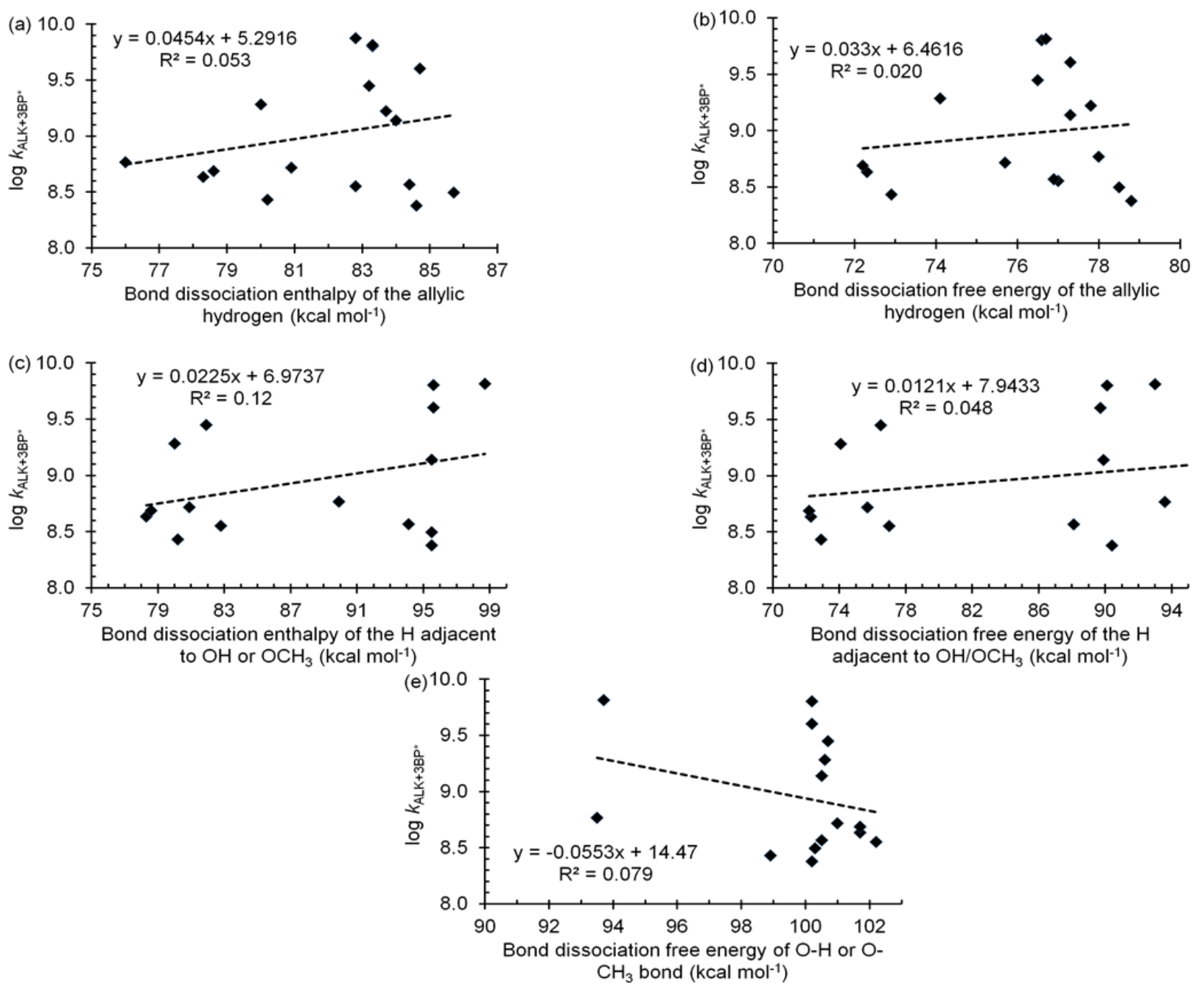

112 Figure S5. Correlation plots for measured rate constants and various computed bond dissociation 113 energies. (a) Log $k_{\mathrm{ALK}+3 \mathrm{BP} *}$ versus the lowest bond dissociation enthalpy of the allylic hydrogen 114 in each alkene (i.e., the green values in Fig. S4). (b) Log $k_{\mathrm{ALK}+3 \mathrm{BP} *}$ versus the lowest bond 115 dissociation free energy of the allylic hydrogen. (c) $\log k_{\mathrm{ALK}+3 \mathrm{BP}} *$ versus the bond dissociation 116 enthalpy of the hydrogen attached to the carbon adjacent to the $-\mathrm{OH}$ or $-\mathrm{OCH}_{3}$ group. (d) $\mathrm{Log}$ $117 k_{\mathrm{ALK}+3 \mathrm{BP}} *$ versus the bond dissociation free energy of the hydrogen attached to the carbon 118 adjacent to the $-\mathrm{OH}$ or $-\mathrm{OCH}_{3}$ group. (e): $\log k_{\mathrm{ALK}+3 \mathrm{BP}} *$ versus bond dissociation free energy of 119 the $\mathrm{O}-\mathrm{H}$ or $\mathrm{OH}_{2} \mathrm{C}-\mathrm{H}$ bond. Bond dissociation energies are shown in Fig. S4. 


\section{$\diamond " S l o w " ~ \diamond " F a s t " ~-T h e o r e t i c a l$}

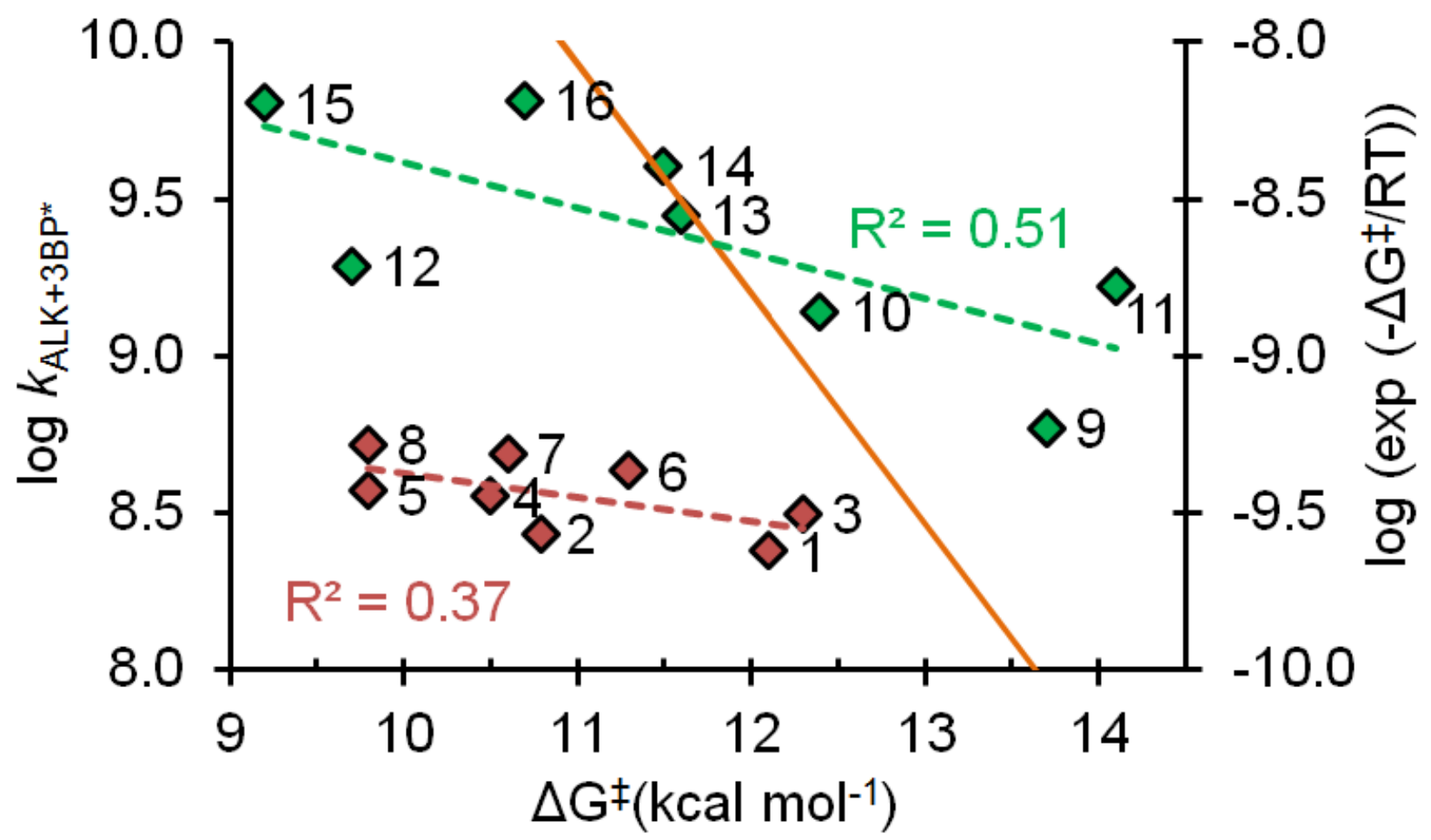

122 Figure S6. $\log k_{\mathrm{ALK}+3 \mathrm{~B}} *$ versus lowest transition state free energy barrier. The alkenes are

123 broken down into two groups: $k_{\mathrm{ALK}+3 \mathrm{BP} *}<5 \times 10^{8} \mathrm{M}^{-1} \mathrm{~s}^{-1}$ (slow, red) and $k_{\mathrm{ALK}+3 \mathrm{BP}} * 5 \times 10^{8} \mathrm{M}^{-}$

$124{ }^{1} \mathrm{~s}^{-1}$ (fast, green). The slopes $( \pm 1 \mathrm{SE})$ of these lines are $-0.077( \pm 0.041)$ and $-0.15( \pm 0.06)$

$125 \mathrm{~mol} \mathrm{kcal}^{-1}$, respectively. Transition state energy barrier values are given in Table 1 of the main

126 text. The orange line (plotted on the secondary $\mathrm{y}$-axis) shows the trend in $k$ values expected from

127 transition state theory $\left(k_{\mathrm{ALK}+3 \mathrm{BP}} *=A \times \exp \left(-\Delta G^{\ddagger} / R T\right)\right)$. 

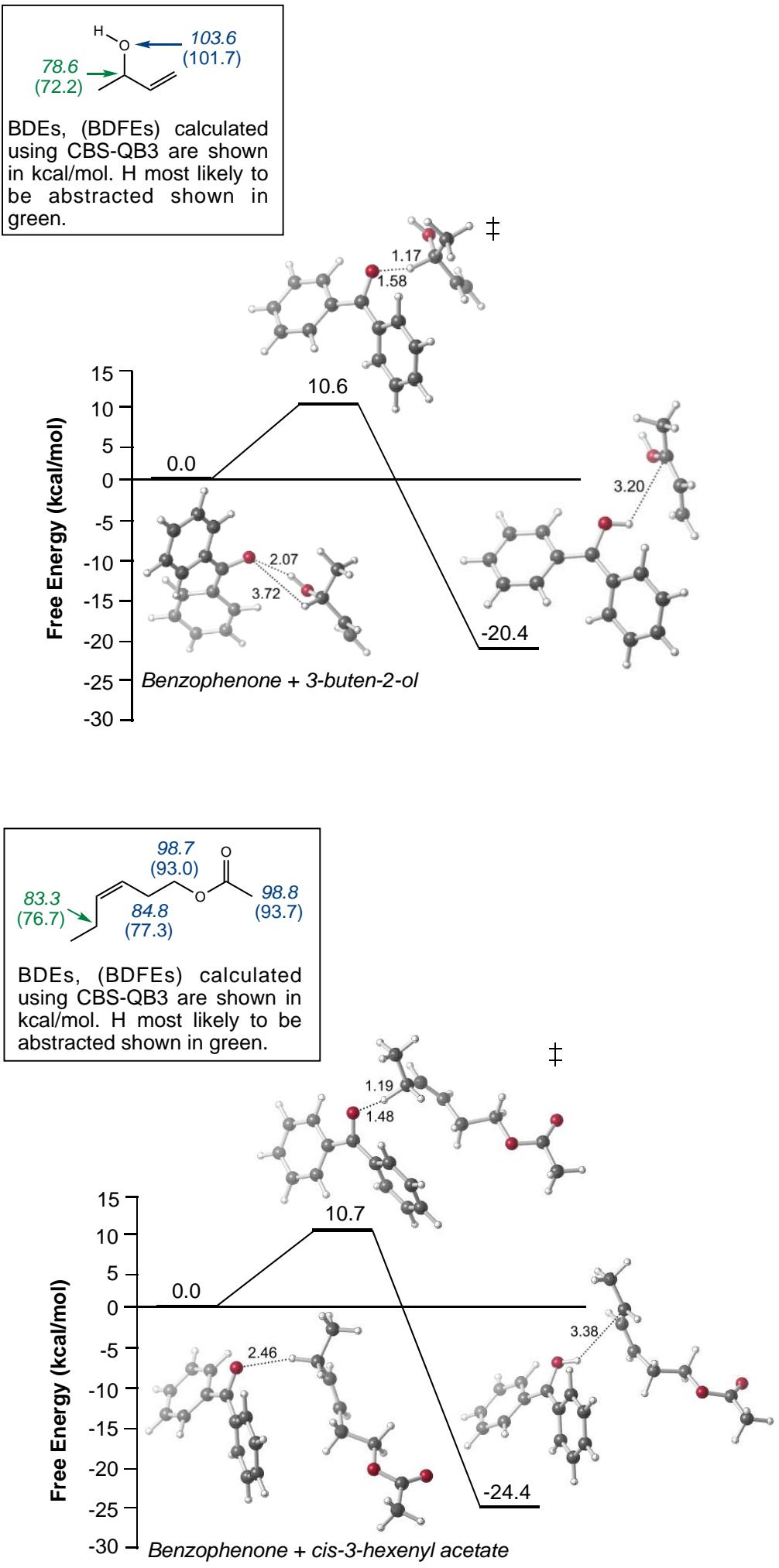

129 Figure S7. Lowest transition state energy barriers for two alkenes: 7, 3B2O, in the top panel and 130 16, cHxAc, in the bottom panel. Both show the hydrogen most likely to be abstracted during 131 oxidation; in both cases this is an allylic $\mathrm{H}$. 


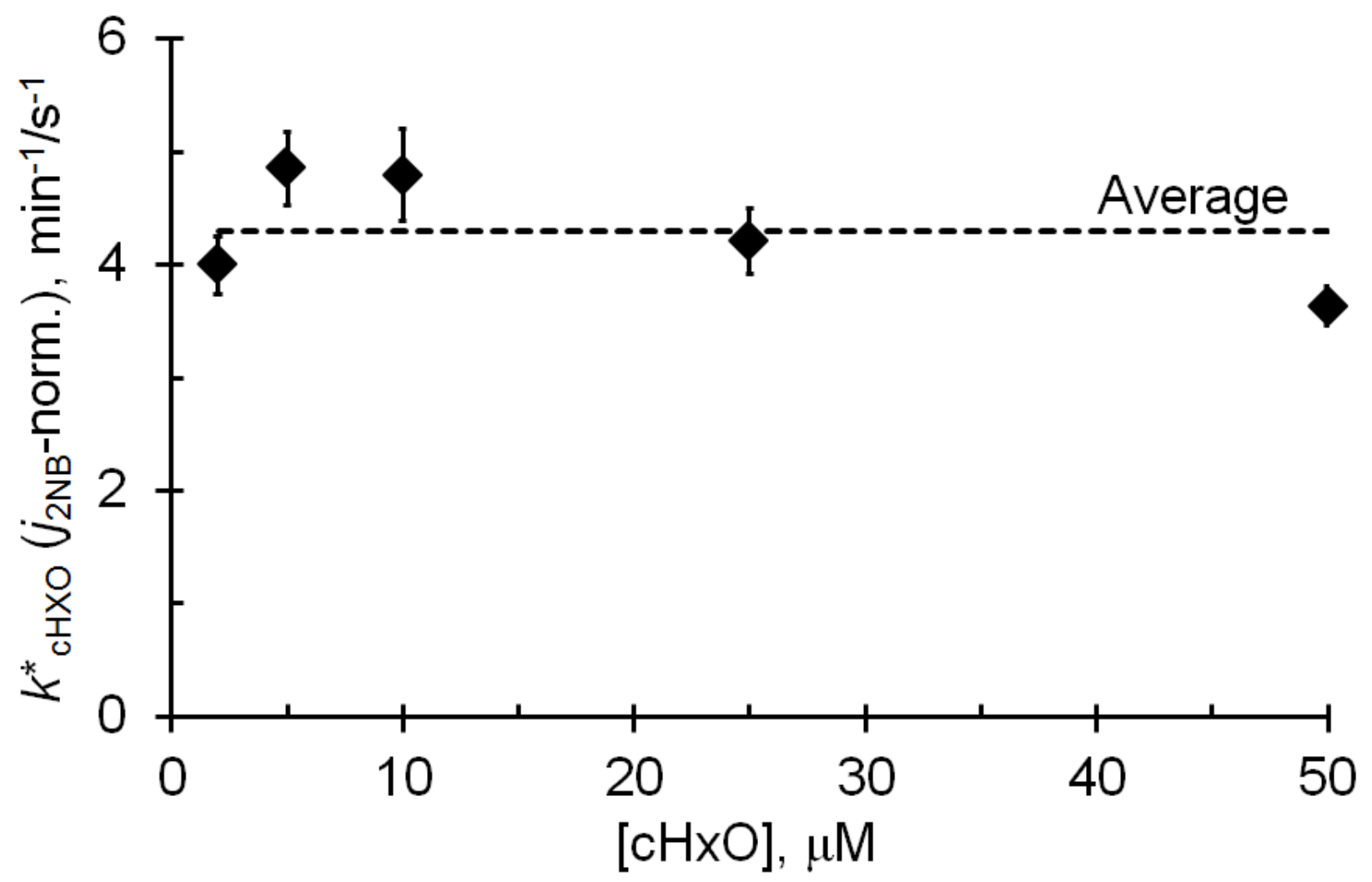

134 Figure S8. Pseudo-first-order loss rate constant of $\mathrm{cHxO}\left(k^{*}{ }_{\mathrm{cHxO}}\right)$ as a function of the

135 concentration of $\mathrm{cHxO}$. Since these experiments were performed on different days, the values are 136 normalized to the photon flux of the illumination system on the day of the experiment by

137 dividing by $j_{2 \mathrm{NB}}$ (details in Kaur and Anastasio (2017)). The average $( \pm 1 \sigma)$ value is $4.3 \pm 0.5$ $138 \mathrm{~min}^{-1} / \mathrm{s}^{-1}$, giving a relative standard deviation of $12 \%$. 


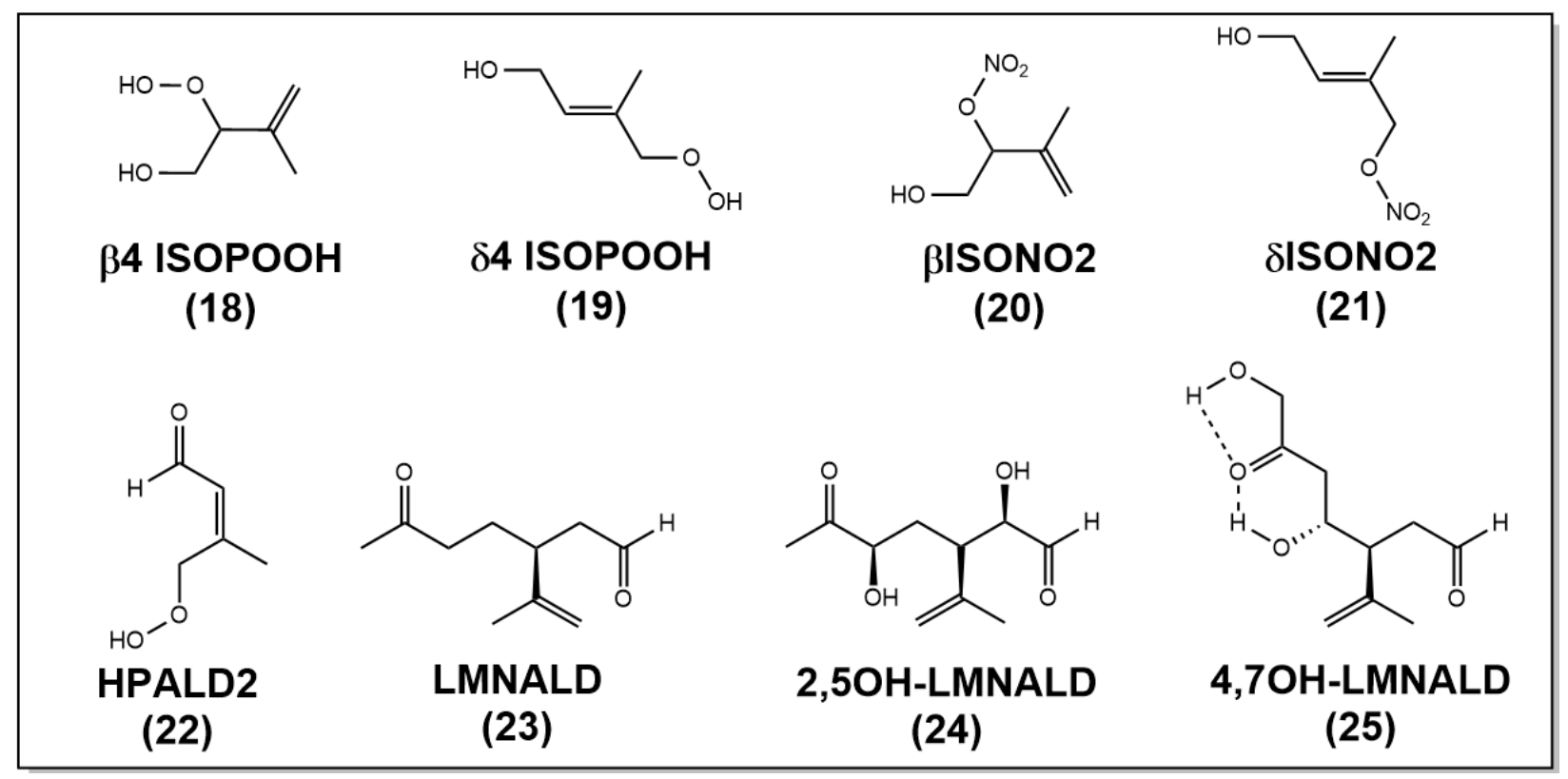

140

Figure S9. Lowest energy isomers of isoprene- and limonene-derived OVOCs, determined with 141 gas-phase calculations using the CBS-QB3 compound method. 


\section{References}

143 Canonica, S., Hellrung, B., and Wirz, J.: Oxidation of phenols by triplet aromatic ketones in aqueous solution, J. Phys. Chem. A, 104, 1226-1232, 2000.

Finlayson-Pitts, B. J., and Pitts Jr, J. N.: Chemistry of the Upper and Lower Atmosphere: Theory, Experiments, and Applications, Academic press, 1999.

Frisch, M., Trucks, G., Schlegel, H., Scuseria, G., Robb, M., Cheeseman, J., Scalmani, G., Barone, V., Petersson, G., Nakatsuji, H., Li, X., Caricato, M., Marenich, A., Bloino, J., Janesko, B., Gomperts, R., Mennucci, B., Hratchian, H., Ortiz, J., Izmaylov, A., Sonnenberg, J., Williams-Young, D., Ding, F., Lipparini, F., Egidi, F., Goings, J., Peng, B., Petrone, A., Henderson, T., Ranasinghe, D., Zakrzewski, V. G., Gao, J., Rega, N., Zheng, G., Liang, W., Hada, M., Ehara, M., Toyota, K., Fukuda, R., Hasegawa, J., Ishida, M., Nakajima, T., Honda, Y., Kitao, O., Nakai, H., Vreven, T., Throssell, K., J. A. Montgomery, J., Peralta, J. E., Ogliaro, F., Bearpark, M., Heyd, J. J., Brothers, E., Kudin, K. N., Staroverov, V. N., Keith, T., Kobayashi, R., Normand, J., Raghavachari, K., Rendell, A., Burant, J. C., Iyengar, S. S., Tomasi, J., Cossi, M., Millam, J. M., Klene, M., Adamo, C., Camml, R., Ochterski, J. W., Martin, R. L., Morokuma, K., Farkas, O., JB, F., and DJ, F.: Gaussian 09, Revision D.01; Gaussian: Wallingford, CT, USA, 2016,

Gill, K. J., and Hites, R. A.: Rate constants for the gas-phase reactions of the hydroxyl radical with isoprene, $\alpha$-and $\beta$-pinene, and limonene as a function of temperature, The Journal of Physical Chemistry A, 106, 2538-2544, 2002.

Herrmann, H., Schaefer, T., Tilgner, A., Styler, S. A., Weller, C., Teich, M., and Otto, T.: Tropospheric aqueous-phase chemistry: Kinetics, mechanisms, and its coupling to a changing gas phase, Chem. Rev., 115, 4259-4334, 2015.

Jacobs, M. I., Burke, W., and Elrod, M. J.: Kinetics of the reactions of isoprene-derived hydroxynitrates: gas phase epoxide formation and solution phase hydrolysis, Atmos. Chem. Phys., 14, 8933-8946, 2014.

Kaur, R., and Anastasio, C.: Light absorption and the photoformation of hydroxyl radical and singlet oxygen in fog waters, Atmos. Environ., 164, 387-397, 2017.

Kaur, R., and Anastasio, C.: First Measurements of Organic Triplet Excited States in Atmospheric Waters, Environ. Sci. Technol., 52, 5218-5226, 2018.

Khamaganov, V. G., and Hites, R. A.: Rate Constants for the Gas-Phase Reactions of Ozone with Isoprene, $\alpha$-and $\beta$-Pinene, and Limonene as a Function of Temperature, The Journal of Physical Chemistry A, 105, 815-822, 2001.

Lee, L., Teng, A. P., Wennberg, P. O., Crounse, J. D., and Cohen, R. C.: On Rates and Mechanisms of OH and $\mathrm{O}_{3}$ Reactions with Isoprene-Derived Hydroxy Nitrates, The Journal of Physical Chemistry A, 118, 1622-1637, 2014.

Madronich, S., Flocke, S., Zeng, J., Petropavlovskikh, I., and Lee-Taylor, J.: Tropospheric UltravioletVisible Model (TUV) version 4.1, National Center for Atmospheric Research, PO Box, 3000, 2002.

Richards-Henderson, N. K., Pham, A. T., Kirk, B. B., and Anastasio, C.: Secondary organic aerosol from aqueous reactions of green leaf volatiles with organic triplet excited states and singlet molecular oxygen, Environ. Sci. Technol., 49, 268-276, 2014.

Rivera-Rios, J. C., Zhao, R., Lee, A. K. Y., Abbatt, J. P. D., Crounse, J. D., Compernolle, S., Wennberg, P. O., and Keutsch, F. N.: In Preparation, 2018.

Schöne, L., and Herrmann, H.: Kinetic measurements of the reactivity of hydrogen peroxide and ozone towards small atmospherically relevant aldehydes, ketones and organic acids in aqueous solutions, Atmos. Chem. Phys., 14, 4503, 2014.

Schöne, L., Schindelka, J., Szeremeta, E., Schaefer, T., Hoffmann, D., Rudzinski, K. J., Szmigielski, R., and Herrmann, H.: Atmospheric aqueous phase radical chemistry of the isoprene oxidation products 
methacrolein, methyl vinyl ketone, methacrylic acid and acrylic acid-kinetics and product studies, Phys. Chem. Chem. Phys., 16, 6257-6272, 2014.

191 Seinfeld, J. H., and Pandis, S. N.: Atmospheric chemistry and physics: From air pollution to climate 192 change, John Wiley \& Sons, 2012.

St. Clair, J. M., Rivera-Rios, J. C., Crounse, J. D., Knap, H. C., Bates, K. H., Teng, A. P., Jørgensen, S., Kjaergaard, H. G., Keutsch, F. N., and Wennberg, P. O.: Kinetics and Products of the Reaction of the First-Generation Isoprene Hydroxy Hydroperoxide (ISOPOOH) with $\mathrm{OH}$, The Journal of Physical Chemistry A, 120, 1441-1451, 2015.

US EPA. Estimation Programs Interface Suite ${ }^{\mathrm{TM}}$ for Microsoft ${ }^{\circledR}$ Windows v 4.1: Estimation Programs Interface Suite ${ }^{\mathrm{TM}}$ for Microsoft ${ }^{\circledR}$ Windows, v 4.1. United States Environmental Protection Agency, Washington, DC, USA., 2016. Oxidation in the Aqueous Phase, Environmental science \& technology, 52, 11583-11590, 2018.

Wolfe, G. M., Crounse, J. D., Parrish, J. D., Clair, J. M. S., Beaver, M. R., Paulot, F., Yoon, T. P., Wennberg, P. O., and Keutsch, F. N.: Photolysis, OH Reactivity and Ozone Reactivity of a Proxy for IsopreneDerived Hydroperoxyenals (HPALDs), Phys. Chem. Chem. Phys., 14, 7276-7286, 2012. 